progression, Prof. Elliot Smith deals with those truly neurological 'bricks', the thalamus and the hypothalamus, the seats respectively of emotional formulation and effective expression, in the light of their special linkages with the cortex itself, facilitating a "cortico-thalamic circulation" which finds functional expression in an enrichment of concepts by the gains of experience of failure or success in past action. While this broadening of the issues involved in what is now known of the fibre relationships of the cortical and thalamic organs is the outstanding feature of Prof. Elliot Smith's lecture, a paragraph--all too brief-must not be overlooked which records the evident complexity of the neural machinery of the parts involved and proceeds to assert that "it becomes essential to look at the whole issue from a much broader point of view than the mere connexions of thalamus and cerebral cortex". The 'key' word of the sentence is 'connexions' and 'mere' is there to turn it vigorously. Is it justifiable to hope that the self-sufficiency of the neurone is at last to be called in question and that the truly organic character of the brain may be substantiated 'in our time'? Is this not a case where the answer has long been prepared and only awaits the application of the question to reveal its fruitfulness ?

\section{Sir George Buchanan, C.B.}

By the retirement of Sir George Buchanan on February 18 from his post as senior medical officer of the Ministry of Health, an association with the public health of Great Britain of nearly forty years is terminated, for Sir George was appointed a medical inspector of the old Local Government Board in 1895. During this period he has accomplished much valuable work over the whole range of public health. In early days he dealt with infectious disease out. breaks, questions of water supply and sewage disposal, housing problems and slum clearance. During the five years 1906-11, he acted as chief inspector of foods, and afterwards was the chief assistant medical officer of the Local Government Board, becoming on the formation of the Ministry of Health its senior medical officer. On the outbreak of War in 1914, Sir George was immediately attached to the Army Sanitary Committee and served on the eastern fronts at Gallipoli and in Macedonia and Mesopotamia, though little mention of the services he rendered there will be found in official records. With the cessation of hostilities commenced his association with the League of Nations. He had been a member of the Health Committee of the League from its foundation, and now became its vice-president, and he also became British representative of the Office International d'Hygiene Publique. In 1919 he was a member of the Poland Typhus Commission instituted by the League of Red Cross Societies, was appointed president of the League of Nations Cancer Commission, and was a member of the League's mission for the public health reorganisation of Greece. In 1926, Sir George was appointed chief British delegate to the International Sanitary Conference. During the last twelve years he has assisted at numerous Government and official investigations.
This bare outline of Sir George Buchanan's activities during his official career suffices to show that he has played a part for which he has earned his country's gratitude.

\section{Dr. Thomas C. Porter}

By the death of Dr. Thomas Porter, for many years science master at Eton College and one of the founders of the (Public Schools) Science Masters' Association, on March 31, aged seventy-three years (Nature, 131, 496, April 8, 1933), science teaching in Great Britain suffered a severe loss. An obituary article in the Journal of the Chemical Society of December 31 stresses Dr. Porter's influence as a teacher. Though he was gifted with remarkable talent, he never allowed himself to specialise. This wide range of interests was the source of inspiration which many of his pupils gained from him. Porter was born at Bristol and was educated at the Grammar School, from which he gained a scholarship in natural science at Exeter College, Oxford, in 1878. In 1885 he was appointed at Eton, and there he taught for forty-eight years. He was responsible for many improvements and extensions in the teaching of science at the College. Dr. Porter's own investigations covered a wide field. His most serious contribution was on the phenomenon of 'flicker', contributed to the Proceedings of the Royal Society in 1898, 1902 and 1912. He was the first to notice the nonhomogeneity of X-rays (Nature, 54, 149, June 18, 1896). Papers on Newton's rings and the use of flames for enhancing the intensity of sound were published in the Philosophical Magazine.

\section{British Industries Fair}

IT has become almost a stereotyped phrase to say of each British Industries Fair that it is larger and more representative than any that have preceded it. The twentieth British Industries Fair to be held in London and Birmingham on February 19-March 2 maintains this tradition. In the London Section the lighter trades and Empire exhibits will be found at Olympia; while the textiles and clothing and the furniture displays will be at the White City. The Birmingham Section at Castle Bromwich comprises hardware, house equipment, engineering and 'heavy' industries generally. At Castle Bromwich there will also be an out-of-doors exhibition for the display and demonstration of agricultural implements, light railways, and quarrying and road-making plant. The trade groups which have shown the most marked growth, judged by the extent of their exhibits at the Fair, are furniture (the biggest section in the Fair) at the White City, electricity and building at Castle Bromwich, and the following groups at Olympia: Government of India, brush-ware and fancy goods; jewellery, pottery and glass-ware; sports goods; stationery, printing and office equipment, etc.; toys and games; chemicals and druggists' sundries. It is interesting to note that the first British Industries Fair, which began as a War-time experiment in 1915 , consisted of about 5 miles of stands at the Royal Agricultural Hall, Islington, whereas the stands of this twentieth Fair, in 1934, extend to about 32 miles 
or, say, fifteen times the length of Oxford Street. Incidentally, it may be noted that twenty-two Continental countries-another record-have given special travel concessions this year to encourage attendance at the Fair by their trades buyers. In these days of quotas and other forms of restrictions on international trade, it is very significant that twenty-two Continental countries should so appreciate the international importance of the British Industries Fair.

\section{Sale of Contraceptives}

ON February 13, Lord Dawson of Penn moved the second reading of the Contraceptives Bill. The provisions of the Bill were dealt with in a leading article in Nature of February 10, p. 192. Lord Dawson said that birth control is now "part and parcel of our social fabric" and that he wished to identify himself with the view that the way to keep the sale and use of contraceptives on sound lines is "to remove the veil of doubt as to the honesty of contraception". Birth control is already accepted in practice, and if there were only wider acceptance of it in theory, the sale of contraceptives would go into normal channels. Meanwhile, he is of opinion that children and young persons require a certain amount of protection such as the bill would afford. Lord Dawson said that he is quite prepared to accept amendments provided that the principle of the bill is not undermined. The Bishop of London, while not agreeing with Lord Dawson, said he would support the Bill enthusiastically, giving as his reason the moral effect of the indiscriminate advertisement and sale of contraceptives. The Archbishop of Canterbury supported the Bill as being a serious attempt to check in some measure the growth of an evil which is poisoning the moral health, self-control and self-respect of the community. The motion for the rejection was negatived by 45 votes to 6 .

\section{Tree-Kangaroos}

THe birth of a tree-kangaroo at the Gardens of the Zoological Society of London is an event well worth recording. Another was born at about this time last year. One would have supposed that the drastic change from the tropical forests of New Guinea and North Australia to a relatively small cage in London would have inhibited the reproductive activities. Even without this added interest, the presence of this strange creature in the Gardens is something more than welcome to all who are concerned with the problems presented by anomalous changes of habit and habitat in the animal kingdom. The typical kangaroo is, in itself, a sufficiently remarkable animal. For here we seem to have a convincing example of 'neo-Lamarckian' changes of form. Though how the initial stage of the leaping habit began we are scarcely likely to discover. It is not merely that the hind-legs and tail have grown inordinately large, but we have also to take into wcount the quite unusual nature of the reduction of the toes; for instead of disappearing on each side of a median axis, the reduction of the second and third toes has taken place on the inner side of the foot, where the claws only are visible in the living animal.

Ir seems clear that the tree-kangaroo must have taken to an arboreal life after this specialisation for terrestrial leaping had taken place; though it is to be noted that, as in the wallabys, the hind-legs are shorter, and the fore-legs relatively larger than in the large ground-dwellers of the tribe. Unfortunately, the opportunity of witnessing the actual birth of any of these animals occurs only on the rarest occasions, and it would seem that even then it is by no means easy to interpret what is seen. It used to be believed that the mother seized the infant at the moment of birth in her lips, and immediately trans. ferred it to the teat in her pouch, to which it attached itself forthwith, and retained its hold continuously for some weeks while its further development took place. For the young, in the kangaroos, are, so to speak, prematurely born, with the limbs only slightly developed. A later account gives a very different version, embracing an astonishing degree of activity on the part of this almost embryonic little body. For it is said to make its way up the fur of the parent and into the pouch, and to find the teat unaided; a course of behaviour one would have deemed impossible.

\section{Emigration Schemes in Australia}

IN an article in NATURE of November 4 on popula. tion problems, reference was made to the failure of emigration for the time being. Commenting on the position, so far as Australia is concerned, Sir James Barrett, of Melbourne, in a letter to the Editor, states that the failure is not so disastrous in Australia as appears on the surface; despite the fact that, in Victoria alone, many millions of pounds will be lost on land settlement schemes. Few people realise that industrial farming requires for success scientific knowledge and training at least equal to that required in any learned profession. In his paper read before the World Population Conference in 1931 the late Prof. J. W. Gregory showed the importance of immigration to Australia in order that a population capable of making the utmost use of railways, etc., should be established in that country as quickly as possible. In Victoria more than $£ 10,000,000$ has been spent on irrigation works which, together with railways, were planned in accordance with a far-seeing land settlement policy. In addition, therefore, to the actual cost of land settlement schemes which the taxpayer, as Sir James Barrett says, is now forced to meet, there is this further heavy expenditure, much of which has been incurred directly for immigration and land settlement. Prof. Gregory also made some interesting references to the varying estimates that, have from time to time been drawn up as to Australia's capacity for supporting a large population. These range very widely, from about $200,000,000$ sstimated by Admiral Sir Edmond Slade to about $10,000,000$ and other similar low estimates made in Australia itself, for example, by F. C. Benham of the University of Sydney. Prof. Gregory's own estimate was more nearly $100,000,000$. 